\title{
Factors affecting survival in liver metastasis of colorectal cancer
}

\author{
Kolorektal kanserin karaciğer metastazında sağ kalımı etkileyen faktörler \\ Osman Bozbıyık@ Ahmet Çoker@ \\ Ege University Faculty of Medicine, Department of General Surgery, Izmir, Turkey
}

\begin{abstract}
Aim: Colorectal cancer is among the most common malignancies and liver metastasis is developed in $50 \%$ of the patients. Hepatic resection is the most effective treatment in liver metastasis of colorectal cancer. The present study aimed to determine the factors that affect survival in patients who underwent hepatic resection in liver metastasis of colorectal cancer.

Materials and Methods: The data on patients who underwent hepatic resection due to liver metastasis of colorectal cancer in Ege University, Faculty of Medicine, General Surgery Department were retrospectively analyzed. Survival data were collected with the review of patient follow-up files. The effects of the factors pertaining to the patients on survival were determined.

Results: The mean age of the 62 participating patients was $58.08 \pm 10.92$ years. Total survival rate was 50.4 months (Cl: 41.2-59.7). The factors that statistically significantly reduced the survival rate were determined as follows: Patient age $>65$ (<65 years: $56.4 \pm 5.5$ months / $\geq 65$ years: $29.3 \pm 4.8$ months, $p=0.007$ ), presence of more than four lymph node metastases in the primary tumor (N0: 56.1 \pm 7.9 months / N1: $56.5 \pm 6.5$ months / N2: $18.0 \pm 3.0, p=0.001)$, presence of bilobular liver metastasis (Uni-lobular: $53.4 \pm 5.0$ months / bilobular: $24.0 \pm 4.4$ months, $p=0.026$ ), and liver resection margin closer than $2 \mathrm{~mm}(<2 \mathrm{~mm}: 28.4 \pm 7.7$ months / 2-9 mm: $61.1 \pm 7,6$ months, $\geq 10 \mathrm{~mm}$ : $46.3 \pm 5.9$ months, $p=0.003$ ). No statistically significant differences were determined in survival based on gender, location of the primary tumor, the invasion depth of the primary tumor, the time between colorectal and liver surgery, the carcinoembryonic antigen level, the metastasis diameter, the number of metastases and the extent of surgical resection.
\end{abstract}

Conclusion: In patients who underwent surgical resection for liver metastasis of colorectal cancer, age older than sixty-five years, the presence of more than four lymph nodes in the colon resection material, bilobular liver metastasis, and a surgical margin closer than $2 \mathrm{~mm}$ were poor prognostic factors.

Keywords: Colon cancer, liver metastasis, rectal cancer, survival analysis.

\section{ÖZ}

Amaç: Kolorektal kanser en sık görülen malignitelerden biridir ve hastaların \%50'sinde karaciğer metastazı gelişir. Kolorektal kanserlerin karaciğer metastazlarında hepatik rezeksiyon en etkili tedavi yöntemidir. Bu çalışmanın amacı kolorektal kanserlerin karaciğer metastazında hepatik rezeksiyon uygulanan hastalarda sağ kalımı etkileyen faktörlerin ortaya konmasıdır.

Gereç ve Yöntem: Ege Üniversitesi Tıp Fakültesi Genel Cerrahi Anabilim Dalı'nda kolorektal kanserin karaciğer metastazı nedeniyle hepatik rezeksiyon uygulanmış olan hastaların verileri retrospektif olarak incelendi. Hastaların takip dosyaları incelenerek sağ kalım verileri elde edildi. Hastalara ait faktörlerin sağ kalıma etkisi değerlendirildi.

Corresponding author: Osman Bozbıyık

Ege University Faculty of Medicine, Department of General

Surgery, Izmir, Turkey

E-mail: bozbiyiko@gmail.com

Application date: 14.01.2021

Accepted: 19.02.2021 


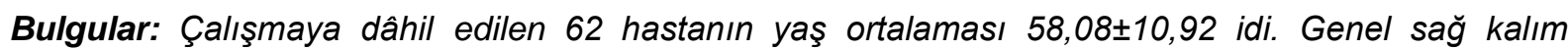
ortalaması 50,4 ay (Cl: 41,2-59,7) olarak saptandı. Hasta yaşının 65'ten büyük olması (<65 yıl:56,4 $\pm 5,5$ ay / $\geq 65$ yıl:29,3 $\pm 4,8$ ay, $p=0,007$ ), primer tümörde dörtten fazla lenf nodu metastazı olması (N0:56,1 $\pm 7,9$ ay/ N1:56,5 $\pm 6,5$ ay/ N2:18,0 $\pm 3,0, p=0,001)$, bilober karaciğer metastazı varlığı

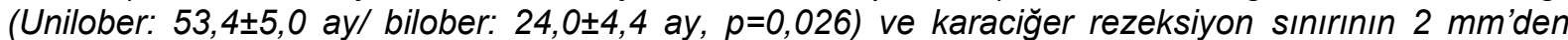
yakın olması (<2 mm: 28,4 $\pm 7,7$ ay/ 2-9 mm:61,1 $\pm 7,6 a y, ~ \geq 10 \mathrm{~mm}: 46,3 \pm 5,9 a y, p=0,003)$ istatistiksel olarak anlamlı şekilde sağ kalımı azaltan faktörler olarak saptandı. Cinsiyet, primer tümörün yerleşimi, primer tümörün invazyon derinliği, kolorektal ve karaciğer cerrahisi arasındaki süre, karsinoembriyonik antijen düzeyi, metastazın çapı, metastaz sayısı ve cerrahi rezeksiyonun genişliği ile sağ kalım süresi arasında istatiksel olarak anlamlı fark saptanmadı

Sonuç: Kolorektal kanserin karaciğer metastazına yönelik cerrahi rezeksiyon uygulanan hastalarda, 65 yaşından büyük olmak, kolon rezeksiyon materyalinde dörtten fazla lenf nodu olması, bilober karaciğer metastazı ve cerrahi sınırın 2 mm'den yakın olması kötü prognostik faktörlerdir.

Anahtar Sözcükler: Kolon kanseri, karaciğer metastazı, rektum kanseri, sağ kalım analizi.

\section{INTRODUCTION}

Colorectal cancer is the third most common cancer in the world with 1.8 million new diagnoses per year and is the second most common cause of cancer mortality (1). Liver metastasis is observed in $50-60 \%$ of colorectal cancer cases during the lifetime (2). The most common metastasis site in colorectal cancers is the liver. Treatment of liver metastases has improved significantly in colorectal cancer during recent years. The resection of liver metastases has significantly improved the survival rate and the chance of cure in colorectal cancer $(3,4)$. These rates improved due to significant improvements in chemotherapeutical agents. Targeted treatments also promise effective results (5). Currently, surgical resection could be performed at higher rates in liver metastases of colorectal cancers through gradual hepatic resections, ablation methods, resection of other isolated organ metastases and neoadjuvant treatment (6).

Several studies demonstrated that potential cure could be possible in patients whose liver metastases could be resect. Advances in both surgical and systemic treatments improved the prognosis of liver metastasis in colorectal cancer during recent years $(4,7)$. However, the controversy on the timing, type of liver resection, and extent of surgery, and optimal chemotherapy continues without any consensus in the literature. The present study aimed to analyze the factors that affect survival in patients who underwent surgical liver metastasis resection in colorectal cancer.

\section{MATERIALS and METHODS}

Adult patients who underwent liver metastasis resection due to colorectal cancer at Ege
University, Faculty of Medicine, General Surgery Department between 2003 and 2009 were included in the study. The retrospective patient data were collected from patient files. Patients' general surgery and oncology follow-up files were examined and the patient status, relapse and survival data at the final follow-up were obtained. Only adult colorectal cancer patients who underwent surgical resection of liver metastasis were included in the study. Patients who underwent microwave ablation, chemoembolization or radiofrequency ablation of the liver metastasis were excluded. Patients with non-colorectal cancer liver metastases were also excluded. In the study, hepatic resection indications were determined as availability of curative resection of primary colorectal cancer, a metastasis limited to only the liver, and availability of adequate liver tissue after resection. The variables, which were investigated for their effect on survival were: age, gender, location of the primary tumor, invasion depth of the primary tumor, lymph node status, time between colorectal and hepatic surgeries, preoperative carcinoembryonic antigen (CEA), diameter of the metastasis, number of metastases, location of metastasis (uni-lobular / bilobular), the extent of surgical resection and the surgical margin.

SPSS Statistics for Windows, version 13.0 (SPSS Inc. Chicago, USA) software was used in statistical analysis. Survival curves were plotted with the Kaplan-Meier method. The analysis of factors that could affect the survival rate was conducted with the Cox-Mental Log-Rank Test. A $p$ value of less than 0.05 was considered significant. 


\section{RESULTS}

Sixty-two colorectal cancer patients with liver metastases who underwent metastasis resection were included in the study. The mean patient age was $58.08 \pm 10.92$, and the median patient age was 58 (24-81). Thirty-four (54.8\%) patients were male and $28(45.2 \%)$ were female. The primary tumor was rectal adenocarcinoma in 26 (41.9\%) patients and colon adenocarcinoma in 36 $(51.8 \%)$ patients. The mean primary tumor diameter was $4.6(2.0-9.0) \mathrm{cm}$. The invasion depth of the primary tumor and lymph node metastasis could be determined in 46 patients and could not be determined in 16 patients. Based on the TNM classification, one patient was T1, one patient was T2, 21 patients were T3, and 23 patients were T4. Lymph node status was determined as follows: 14 patients were N0, 21 patients were $\mathrm{N} 1$, and 11 patients were N2. The time between primary tumor and liver metastasis interventions was classified into three groups. Thus, primary tumor surgery and liver metastasis surgery was performed in the same operation in nine patients, there was less than one year between the two surgeries in 27 patients, and there was more than one year between the two surgeries in 26 patients.

In six participating patients, it was determined liver metastases were not adequate for resection at the time of initial diagnosis, but resection was suitable after chemotherapy. While the CEA serum level was below the $5 \mathrm{ng} / \mathrm{ml}$ reference value in our hospital in 22 patients, and it was above this value in 32 patients before the liver surgery, and CEA serum level was not determined in eight patients. The mean diameter of the largest liver metastasis was 3.9 (1.1-9.0) $\mathrm{cm}$. While the diameter of the largest liver metastasis was less than $5 \mathrm{~cm}$ in $44(71.0 \%)$ patients, it was greater than $5 \mathrm{~cm}$ in $18(29.0 \%)$ patients. Solitary liver metastases were observed in $36(58.1 \%)$ patients, there were two metastases in $15(24.2 \%)$, three in eight $(12.9 \%)$, and four in three $(4.8 \%)$ patients. Liver metastases were uni-lobular in 54 (87.1\%) patients, and bilobular in eight (12.9\%) patients. Segmentectomy or smaller resections were performed in $29(46.8 \%)$ patients, and larger resections were performed in $33(53.2 \%)$ patients (Table-1). Histologically, the tumor was closer than $2 \mathrm{~mm}$ to the surgical margin in $14(22.6 \%)$ patients. In $26(41.9 \%)$ patients, the tumor was more than $2 \mathrm{~mm}$ distant but closer than $1 \mathrm{~cm}$ to the surgical margin, and in $22(35.5 \%)$ patients, the tumor was farther than $1 \mathrm{~cm}$ to the surgical margin.

The mean survival of the whole group was 50.4 months (Cl: 41.2-59.7). The median survival was 49 months, and the shortest survival was 0.5 months. Mortality developed in the early postoperative period in two patients. The first patient died on postoperative 15th day due to liver failure, and the other patient died on the 2nd month due to pneumonia.

It was determined that poor prognosis factors included an age older than 65 during liver metastasis surgery, the presence of more than four lymph nodes within the colon resection material, presence of bilobular liver metastasis, and a surgical margin closer than $2 \mathrm{~mm}$ (Figure1). No statistically significant difference was determined between the survival length based on gender, location of the primary tumor, the invasion depth of the primary tumor, the time between colorectal and liver surgery, the preoperative carcinoembryonic antigen (CEA) level, the metastasis diameter, the number of metastases, and the extent of surgical resection (Table-2).

Table-1. Surgical methods in hepatic resection.

\begin{tabular}{|c|c|c|c|}
\hline & & $\begin{array}{l}\text { Frequency } \\
\text { (n:62) }\end{array}$ & Rate (\%) \\
\hline \multirow[t]{6}{*}{ Major resection } & Right hepatectomy & 18 & 29.0 \\
\hline & Right hepatectomy + metastasectomy & 2 & 3.2 \\
\hline & Right posterior sectoralectomy & 1 & 1.6 \\
\hline & Left hepatectomy & 8 & 12.9 \\
\hline & Left lateral sectoralectomy & 1 & 1.6 \\
\hline & Left lateral sectoralectomy + metastasectomy & 3 & 4.8 \\
\hline \multirow[t]{2}{*}{ Minor resection } & Segmentectomy & 11 & 17.7 \\
\hline & Metastasectomy & 18 & 29.0 \\
\hline
\end{tabular}


Table-2. The impact of patient variables on survival.

\begin{tabular}{|c|c|c|c|c|c|c|c|}
\hline & & $\begin{array}{c}\text { Frequency } \\
\text { (n:62) }\end{array}$ & $\begin{array}{l}\text { 1-year } \\
\text { survival }\end{array}$ & $\begin{array}{l}\text { 5-year } \\
\text { survival }\end{array}$ & $\begin{array}{l}\text { Mean } \\
\text { survival } \\
\text { (month) }\end{array}$ & $\begin{array}{l}\text { Standard } \\
\text { deviation }\end{array}$ & $\mathbf{p}$ \\
\hline \multirow[t]{2}{*}{ Age } & $<65$ & $46(\% 74.2)$ & $\% 89.1$ & $\% 45.1$ & $56.4 \pm 5.5$ & $45.6-67.2$ & \multirow[t]{2}{*}{0.007} \\
\hline & $\geq 65$ & $16(\% 25.8)$ & $\% 68.8$ & $\% 0$ & $29.3 \pm 4.8$ & 19.7-38.9 & \\
\hline \multirow[t]{2}{*}{ Gender } & Female & $28(\% 45.2)$ & $\% 85.7$ & \% 53.9 & $52.8 \pm 6.1$ & $40.8-64.9$ & \multirow[t]{2}{*}{0.225} \\
\hline & Male & 34 (\% 54.8) & \% 82.4 & $\% 22.1$ & $46.1 \pm 6.1$ & $34.1-52.0$ & \\
\hline \multirow{2}{*}{$\begin{array}{l}\text { Primary } \\
\text { focus }\end{array}$} & Colon & $36(\% 58.1)$ & $\% 86.1$ & $\% 43.5$ & $56.3 \pm 6.2$ & $44.1-68.4$ & \multirow[t]{2}{*}{0.077} \\
\hline & Rectum & $26(\% 41.9)$ & \% 80.8 & $\% 24.4$ & $39.1 \pm 5.9$ & $27.3-50.8$ & \\
\hline \multirow{2}{*}{$\begin{array}{l}\text { Invasion } \\
\text { depth }\end{array}$} & T3 & $21(\% 33.8)$ & $\% 76.2$ & $\% 31.4$ & $41.3 \pm 6.7$ & $28.2-54.5$ & \multirow[t]{2}{*}{0.545} \\
\hline & $\mathrm{T} 4$ & $23(\% 37.1)$ & $\% 95.7$ & $\% 21.0$ & $43.1 \pm 4.0$ & $33.8-70.1$ & \\
\hline \multirow{3}{*}{$\begin{array}{l}\text { Lymph } \\
\text { Node }\end{array}$} & No & $14(\% 22.6)$ & $\% 100$ & $\% 44.1$ & $56.1 \pm 7.9$ & $40.6-71.7$ & \multirow{3}{*}{$\begin{array}{l}0.96 \\
\mathbf{0 . 0 0 1}\end{array}$} \\
\hline & $\mathrm{N} 1$ & $21(\% 33.9)$ & $\% 90.5$ & $\% 42.5$ & $56.5 \pm 6.5$ & $43.7-69.2$ & \\
\hline & N2 & $11(\% 17.7)$ & $\% 63.6$ & $\% 0$ & $18.0 \pm 3.0$ & 12. 0-23.9 & \\
\hline \multirow{3}{*}{$\begin{array}{l}\text { Surgical } \\
\text { interval }\end{array}$} & Concurrent & $9(\% 14.5)$ & \% 88.9 & $\% 33.3$ & $52.4 \pm 10.6$ & $31.6-73.2$ & \multirow{3}{*}{$\begin{array}{l}0.56 \\
0.79\end{array}$} \\
\hline & $<1$ year & 27 (\% 43.5) & $\% 81.5$ & $\% 33.8$ & $46.4 \pm 6.7$ & $33.1-59.6$ & \\
\hline & $\geq 1$ year & $26(\% 41.9)$ & $\% 84.6$ & $\% 37.3$ & $48.6 \pm 6.4$ & $36.0-61.3$ & \\
\hline \multirow[t]{2}{*}{ CEA level } & $\leq 5 \mathrm{ng} / \mathrm{ml}$ & $22(\% 35.4)$ & \% 81.8 & $\% 38.3$ & $50.8 \pm 7.1$ & $36.8-64.8$ & \multirow[t]{2}{*}{0.407} \\
\hline & $>5 \mathrm{ng} / \mathrm{ml}$ & $32(\% 51.6)$ & \% 84.4 & $\% 30.6$ & $41.8 \pm 4.9$ & $32.1-51,6$ & \\
\hline \multirow[t]{2}{*}{ CEA level } & $\leq 200 \mathrm{ng} / \mathrm{ml}$ & $50(\% 80.6)$ & $\% 77.9$ & \%33.7 & $46.8 \pm 4.3$ & 38.3-55.3 & \multirow[t]{2}{*}{0.497} \\
\hline & $>200 \mathrm{ng} / \mathrm{ml}$ & $4(\% 6.4)$ & $\% 50.0$ & $\% 25.0$ & $26.5 \pm 13.5$ & $0.1-52.9$ & \\
\hline \multirow{2}{*}{$\begin{array}{l}\text { Metastasis } \\
\text { diameter }\end{array}$} & $<5 \mathrm{~cm}$ & $44(\% 70.9)$ & \% 86.4 & $\% 36.1$ & $52.5 \pm 5.5$ & 41.7-63.4 & \multirow[t]{2}{*}{0,520} \\
\hline & $\geq 5 \mathrm{~cm}$ & $18(\% 29.0)$ & $\% 77.8$ & $\% 34.3$ & $42.4 \pm 7.7$ & $27.2-57.7$ & \\
\hline \multirow[t]{2}{*}{ Location } & Uni-lobular & $54(\% 87.1)$ & \% 83.3 & \% 39.6 & $53.4 \pm 5.0$ & 43.4-63.3 & \multirow[t]{2}{*}{0,026} \\
\hline & Bilobular & $8(\% 12.9)$ & \% 87.5 & $\% 0$ & $24.0 \pm 4.4$ & $15.4-32.6$ & \\
\hline \multirow{2}{*}{$\begin{array}{l}\text { Resection } \\
\text { Width * }\end{array}$} & Minor & $29(\% 46.8)$ & \% 89.7 & $\% 45.8$ & $54.7 \pm 7.1$ & $40.6-68.8$ & \multirow[t]{2}{*}{0.428} \\
\hline & Major & $33(\% 53.2)$ & \% 78.8 & $\% 29.0$ & $44.6 \pm 5.4$ & $33.9-55.3$ & \\
\hline \multirow{3}{*}{$\begin{array}{l}\text { Surgical } \\
\text { margin }\end{array}$} & $<2 \mathrm{~mm}$ & $14(\% 22.6)$ & $\% 57.1$ & $\% 12.9$ & $28.4 \pm 7.7$ & $13.1-43.7$ & \multirow{3}{*}{$\begin{array}{l}0.003 \\
0.290\end{array}$} \\
\hline & $2-9 \mathrm{~mm}$ & $26(\% 41.9)$ & $\% 96.2$ & $\% 48.5$ & $61.1 \pm 7.6$ & $46.0-76.2$ & \\
\hline & $\geq 1 \mathrm{~cm}$ & 22 (\%35.5) & $\% 86.4$ & $\% 36.0$ & $46.3 \pm 5.9$ & $34.6-58.1$ & \\
\hline
\end{tabular}

Minor resection: Segmentectomy or metastasectomy, Major resection: A hepatectomy larger than segmentectomy. 

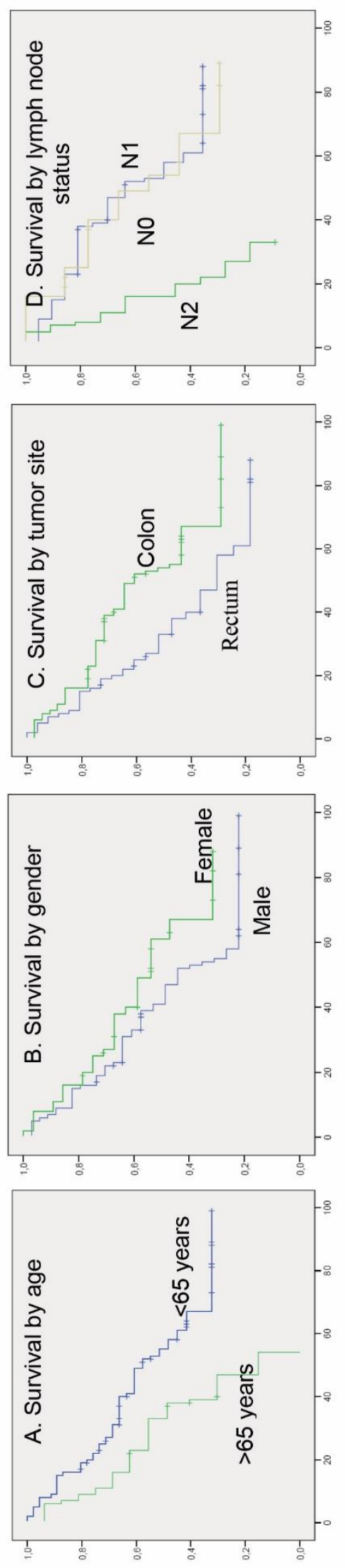
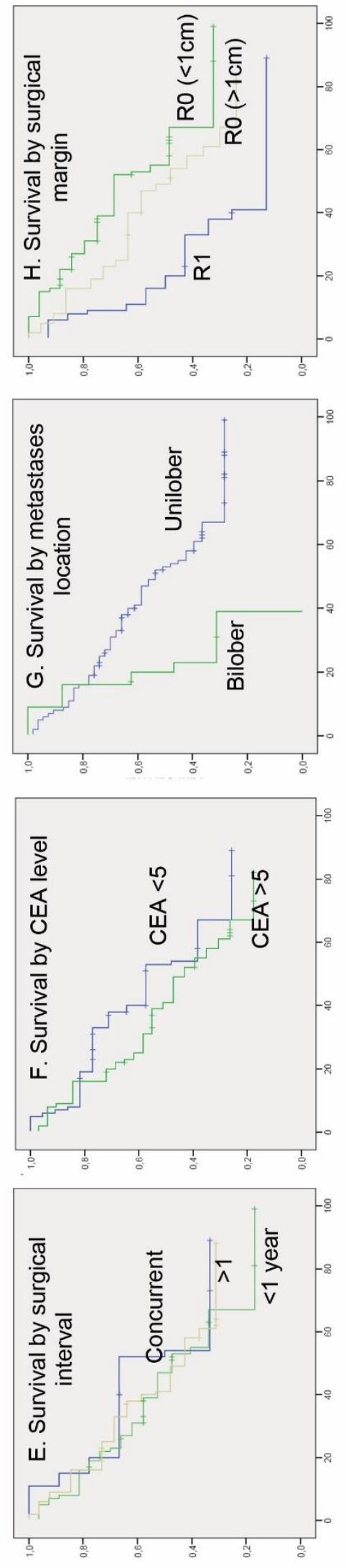

20 


\section{DISCUSSION}

Currently, surgical resection is the gold standard treatment in adequate colorectal cancer cases with liver metastasis. Despite advances in chemotherapy, resection is still the only treatment that could lead to cure $(4,5)$. In 1940, Richard B. Cattell resected liver metastasis of colorectal cancer for the first time (8). However, due to high mortality rates, resection of metastases remained a controversial issue until the 1980s. In 1984, Wagner et al. reported that a significant increase in survival was achieved with surgical resection in colorectal cancer liver metastases (9). After this report, interest in the subject has gradually increased. The resection indications in colorectal liver metastases were limited to less than four metastases, lack of extrahepatic disease, and 1 $\mathrm{cm}$ surgical margin for a long time (10). Today, the indications are expanded, and resection conditions include a negative surgical margin, preservation of at least two segments including vascular and biliary structures, and a more than $20 \%$ remaining healthy liver parenchyma (7).

Factors that affect survival in liver metastasis of colorectal cancer were investigated by various teams to develop prognostic scoring systems. Nordlinger et al. were the first group to develop a prognostic scoring system. In the analysis they conducted on 1568 patients in 85 clinics in France with an average follow-up period of 19 months, the factors that affected the prognosis were reported as over 60 years of age, excess serosa in the primary tumor, lymph node metastasis in the primary tumor, development of liver metastasis during the initial two years, larger than $5 \mathrm{~cm}$ liver metastasis diameter, more than four liver metastases, and shorter than $1 \mathrm{~cm}$ surgical margin (11). The scoring system developed by Fong et al. in the Memorial SloanKettering Cancer Center is the best-known prognostic score system. In their study, seven prognostic factors were identified. These prognostic factors were lymph node involvement in the primary tumor, development of liver metastasis within the first year, multiple liver metastases, greater than $5 \mathrm{~cm}$ largest liver metastasis diameter, above $200 \mathrm{ng} / \mathrm{ml}$ CEA, other involvement in addition to the liver, and presence of a tumor at the surgical margin (12).

In the present study, 62 colorectal cancer patients who underwent liver metastasis resection in Ege University Hospital were analyzed retrospectively for the factors that affected survival. It was determined that an age over 65 was one of the risk factors that reduced survival. It is known that advanced age is associated with poor prognosis in colorectal cancer (13). In larger case series, it was demonstrated that an age of over 60 in patients who underwent liver metastasis surgery was associated with poor prognosis (11).

The most important factor that determines survival in colorectal cancer is the stage of the disease (14). In our series, no statistically significant difference was determined between the groups based on invasion depth $(T)$ in the analysis conducted based on the tumor stage $(p=$ 0.545). The analysis of the lymph node metastasis $(\mathrm{N})$ demonstrated that primary tumor involvement with more than four lymph nodes was a prognostic factor. Survival was statistically significantly lower in the N2 group when compared to the N0 and N1 groups $(p=0.000, p=$ 0.003). In liver metastases of colorectal cancer, Schindl et al. included Duke stage of the primary tumor, Fong and Rees included lymph node metastasis of the primary tumor in their prognostic score system $(12,15,16)$. In another study, it was reported that lymph node metastasis of the primary tumor affected disease-free survival after liver resection (17).

Liver metastasis is detected in $20-30 \%$ of colorectal cancers during the diagnosis (18). Synchronous liver metastasis has been evaluated as a poor prognostic factor in several studies. Nordlinger included the detection of liver metastasis during the first 2 years, Fong during the first 1 year, Iwatsuki and Zakaria during the first 30 months as indicators of poor prognosis in their respective prognostic score systems (11, $12,19,20)$. There is no consensus on this issue in the literature. According to certain studies, synchronous or metachronous liver metastasis or the time between the two surgeries did not have an effect on prognosis (21). In the present study, there were no significant differences between the survival lengths of 9 patients who underwent liver metastasis surgery in the same operation, of 27 patients where there was less than a year between the two surgeries, and of 26 patients where there was more than one year between the two surgeries.

Several studies reported that pre-resection serum tumor markers, especially the CEA level, were a prognostic factor in liver metastasis of colorectal cancer. In most studies, a CEA threshold value of 
higher than $5 \mathrm{ng} / \mathrm{ml}(60 \mathrm{ng} / \mathrm{ml}, 100 \mathrm{ng} / \mathrm{ml}, 200$ $\mathrm{ng} / \mathrm{ml}$ ) was accepted as a prognostic factor (12, 16, 17 and 22). In the present study, it was determined that a CEA of $5 \mathrm{ng} / \mathrm{ml}$ or above had no impact on survival $(p=0.400)$. There were only four patients whose CEA levels were above $200 \mathrm{ng} / \mathrm{ml}$ before liver metastasis surgery, and no significant difference was determined in survival $(p=0.49)$. Although there was a significant difference between the survival in the groups, but the difference was not statistically significant difference due to the small number of patients with above $200 \mathrm{ng} / \mathrm{ml}$ CEA levels.

In the present study, bilobular liver metastasis was determined as one of the factors that reduced survival. The correlations between liver metastasis diameter, multiple and bilobular location and poor prognosis were shown in several studies. Nordlinger (11) included greater than $5 \mathrm{~cm}$ metastasis diameter and the presence of more than four metastases, Fong (12) included greater than $5 \mathrm{~cm}$ metastasis diameter and the presence of more than one metastasis, Schindl (15) included the presence of more than three metastases, Zakaria (16) included greater than 8 $\mathrm{cm}$ metastasis, Rees (19) included greater than 5 $\mathrm{cm}$ metastasis diameter and the presence of more than one metastasis, Iwatsuki (20) included greater than $8 \mathrm{~cm}$ metastasis diameter, the presence of more than two metastases, and bilobular metastasis among the poor prognosis factors. There was no statistically significant difference between more than $5 \mathrm{~cm}$ metastasis diameter, the number of metastases, and survival in the present study. However, it was determined that bilobular metastasis was a poor prognosis factor.

Unlike other factors that affect the prognosis, surgery is a parameter that could be partially determined by the surgeon. Despite the lack of adequate evidence, it has been generally accepted that the distance between the surgical margin and the tumor should be $1 \mathrm{~cm}$ or more in the liver metastasis of colorectal cancer for many years (23). In the series published by Ekberg, it was argued that the surgical margin should be over $1 \mathrm{~cm}$ and resection should not be conducted in cases where a $1 \mathrm{~cm}$ surgical margin cannot be obtained (10). Certain other series also supported this approach $(24,25)$. However, currently, the $1 \mathrm{~cm}$ rule is debated (26). Kukudo and Nuzzo demonstrated that the $2 \mathrm{~mm}$ and 5 $\mathrm{mm}$ surgical margins and the $1 \mathrm{~cm}$ surgical margin had similar results $(27,28)$. Certain recent studies argued that $\mathrm{R} 0$ resection when there is no tumor at the surgical margin was sufficient regardless of the distance to the surgical margin, and the distance to the margin was insignificant $(29,30)$. In our series, it was determined that survival was shorter in patients where the surgical margin was closer than $2 \mathrm{~mm}$. No statistically significant difference was determined between the survival length of patients with a distance of over $1 \mathrm{~cm}$ between the surgical margin and tumor and those where the same distance was less than $1 \mathrm{~cm}(1-9 \mathrm{~mm})$. The present study findings supported that R0 resection with a $2 \mathrm{~mm}$ surgical margin was sufficient, and resection should be performed in cases without a $1 \mathrm{~cm}$ surgical margin.

The limitations of the current study included the single-center and retrospective design, limited number of patients, and the employment of only general survival as a prognostic factor. Despite these limitations, the fact that the study presented prospective data recorded by a reference hospital in Turkey where advanced hepatobiliary surgeries are conducted, availability of the survival status of all patients demonstrated that the present study perfectly reflected the represented population data.

\section{CONCLUSION}

The present study demonstrated that age of over 65 , more than three lymph node involvement in the primary tumor, bilobular liver metastasis, and a surgical margin closer than $2 \mathrm{~mm}$ were poor prognosis factors in liver metastasis of colorectal cancer. It was determined that a distance of the tumor to the surgical margin lower than $1 \mathrm{~cm}$ did not affect survival in patients who did not have a tumor at the surgical margin. These findings supported that $\mathrm{R} 0$ resection was sufficient in liver metastasis of colorectal cancer, and hepatic resection should be conducted in cases where 1 $\mathrm{cm}$ surgical margin could not be achieved.

\section{Conflict of Interest}

The authors reported no conflict of interest.

Acknowledgements: We would like to thank Ömer Vedat Ünalp, Rasim Farajov, Levent Yeniay, Tayfun Yoldaş and Ethem Murat Sözbilen for their contribution to the data collection stage. 


\section{References}

1. Bray F, Ferlay J, Soerjomataram I, Siegel RL, Torre LA, Jemal A. Global cancer statistics 2018: GLOBOCAN estimates of incidence and mortality worldwide for 36 cancers in 185 countries. CA Cancer J Clin. 2018 Nov $1 ; 68$ (6): 394-424.

2. Kemeny $\mathrm{N}$. The management of resectable and unresectable liver metastases from colorectal cancer. Vol. 22, Current Opinion in Oncology. Curr Opin Oncol; 2010. p. 364-73.

3. Ünal NG, Coşgun G, Korkut M, Özütemiz AÖ, Doğanavşargil B, Çakar B, et al. Ege Üniversitesi Tıp Fakültesi veri tabanındaki kolorektal kanserli olguların epidemiyolojik ve genel sağ kalım özellikleri. Ege Tıp Derg. 2019 Dec 31; 58: 68-77.

4. Rashidian N, Alseidi A, Kirks RC. Cancers Metastatic to the Liver. Vol. 100, Surgical Clinics of North America. W.B. Saunders; 2020. p. 551-63.

5. Varol U, Karaca B, Cakar B, Sezgin C, Karabulut B, Uslu R. Comparing time to disease progression of irinotecan and oxaliplatin-based chemotherapies in colorectal cancer patients with liver only metastasis. Vol. 36, American Journal of Clinical Oncology: Cancer Clinical Trials. Am J Clin Oncol; 2013. p. 388-91.

6. Cokmert S, Ellidokuz H, Demir L, Fuzun M, Astarcioglu I, Aslan D, et al. Survival outcomes of liver metastasectomy in colorectal cancer cases: A single-center analysis in Turkey. Asian Pacific J Cancer Prev. 2014; 15 (13): 5195-200.

7. Adams RB, Aloia TA, Loyer E, Pawlik TM, Taouli B, Vauthey JN. Selection for hepatic resection of colorectal liver metastases: Expert consensus statement. HPB. 2013 Feb 1; 15 (2): 91-103.

8. Cattell R. Successful removal of a liver metastasis from carcinoma of the rectum. Lahey Clin Bull. 1940; (2): 7-11.

9. Wagner JS, Adson MA, van Heerden JA, Adson MH, Ilstrup DM. The natural history of hepatic metastases from colorectal cancer. A comparison with resective treatment. Ann Surg. 1984; 199 (5): 502-8.

10. Ekberg H, Tranberg K -G, Andersson R, Lundstedt C, Hägerstrand I, Ranstam J, et al. Determinants of survival in liver resection for colorectal secondaries. Br J Surg. 1986; 73 (9):727-31.

11. Nordlinger B, Guiguet M, Vaillant JC, Balladur P, Boudjema K, Bachellier P, et al. Surgical resection of colorectal carcinoma metastases to the liver: A prognostic scoring system to improve case selection, based on 1568 patients. Cancer. 1996 Apr 1; 77 (7): 1254-62.

12. Fong $\mathrm{Y}$, Fortner J, Sun RL, Brennan MF, Blumgart LH. Clinical score for predicting recurrence after hepatic resection for metastatic colorectal cancer: Analysis of 1001 consecutive cases. In: Annals of Surgery. Ann Surg; 1999. p. 309-21.

13. Di Giorgio A, Tocchi A, Puntillo G, Botti G, Derme G, Basso L, et al. Age as a prognostic factor following excisional surgery for colorectal cancer. Ann Ital Chir. 1990;61(6):647-50.

14. Amin MB, Greene FL, Edge SB, Compton CC, Gershenwald JE, Brookland RK, et al. The Eighth Edition AJCC Cancer Staging Manual: Continuing to build a bridge from a population-based to a more "personalized" approach to cancer staging. CA Cancer J Clin. 2017 Mar; 67 (2): 93-9.

15. Schindl M, Wigmore SJ, Currie EJ, Laengle F, Garden OJ. Prognostic scoring in colorectal cancer liver metastases: Development and validation. Arch Surg. 2005 Feb; 140 (2): 183-9.

16. Rees M, Tekkis PP, Welsh FKS, O'Rourke T, John TG. Evaluation of long-term survival after hepatic resection for metastatic colorectal cancer: A multifactorial model of 929 patients. Ann Surg. 2008 Jan; 247 (1): $125-35$.

17. Konopke R, Kersting S, Distler M, Dietrich J, Gastmeier J, Heller A, et al. Prognostic factors and evaluation of a clinical score for predicting survival after resection of colorectal liver metastases. Liver Int. 2009; 29 (1): 89-102.

18. Engstrand J, Nilsson H, Strömberg C, Jonas E, Freedman J. Colorectal cancer liver metastases - a population-based study on incidence, management and survival. BMC Cancer. 2018 Jan 15; 18 (1): 78.

19. Iwatsuki S, Dvorchik I, Madariaga JR, Wallis Marsh J, Dodson F, Bonham AC, et al. Hepatic resection for metastatic colorectal adenocarcinoma: A proposal of a prognostic scoring system. J Am Coll Surg. 1999 Sep; 189 (3): 291-9.

20. Zakaria S, Donohue JH, Que FG, Farnell MB, Schleck CD, Ilstrup DM, et al. Hepatic resection for colorectal metastases: Value for risk scoring systems? Vol. 246, Annals of Surgery. Ann Surg; 2007. p. 183-91. 
21. Silberhumer GR, Paty PB, Temple LK, Araujo RLC, Denton B, Gonen M, et al. Simultaneous resection for rectal cancer with synchronous liver metastasis is a safe procedure. Am J Surg. 2015 Jun 1; 209 (6): 935-42.

22. Nikfarjam M, Shereef S, Kimchi ET, Gusani NJ, Jiang Y, Avella DM, et al. Survival outcomes of patients with colorectal liver metastases following hepatic resection or ablation in the era of effective chemotherapy. Ann Surg Oncol. $2009 \mathrm{Jul} ; 16$ (7): 1860-7.

23. Poultsides GA, Schulick RD, Pawlik TM. Hepatic resection for colorectal metastases: The impact of surgical margin status on outcome. HPB. 2010; 12 (1): 43-9.

24. Cady B, Jenkins RL, Steele GD, Lewis WD, Stone MD, McDermott W V., et al. Surgical margin in hepatic resection for colorectal metastasis: A critical and improvable determinant of outcome. Ann Surg. 1998 Apr; 227 (4): 566-71.

25. Wakai T, Shirai Y, Sakata J, Valera VA, Korita P V., Akazawa K, et al. Appraisal of $1 \mathrm{~cm}$ hepatectomy margins for intrahepatic micrometastases in patients with colorectal carcinoma liver metastasis. Ann Surg Oncol. 2008 Sep; 15 (9): 2472-81.

26. Margonis GA, Sergentanis TN, Ntanasis-Stathopoulos I, Andreatos N, Tzanninis IG, Sasaki K, et al. Impact of Surgical Margin Width on Recurrence and Overall Survival Following R0 Hepatic Resection of Colorectal Metastases: A Systematic Review and Meta-analysis. Ann Surg. 2018 Jun 1; 267 (6): 1047-55.

27. Kokudo N, Miki Y, Sugai S, Yanagisawa A, Kato Y, Sakamoto Y, et al. Genetic and histological assessment of surgical margins in resected liver metastases from colorectal carcinoma: Minimum surgical margins for successful resection. Arch Surg. 2002; 137 (7): 833-40.

28. Nuzzo G, Giuliante F, Ardito F, Vellone M, Giovannini I, Federico B, et al. Influence of surgical margin on type of recurrence after liver resection for colorectal metastases: a single-center experience. Surgery. 2008 Mar; 143 (3): 384-93.

29. Hamady ZZR, Lodge JPA, Welsh FK, Toogood GJ, White A, John T, et al. One-millimeter cancer-free margin is curative for colorectal liver metastases: A propensity score case-match approach. Ann Surg. 2014 Mar; 259 (3): 543-8.

30. Pawlik TM, Vauthey JN. Surgical margins during hepatic surgery for colorectal liver metastases: Complete resection not millimeters defines outcome. Vol. 15, Annals of Surgical Oncology. Ann Surg Oncol; 2008. p. $677-9$. 